\title{
Training Librarians for 21st Century Repository Services: Emerging Trends
}

\author{
Helen U. Emasealu and Susan N. Umeozor \\ Donald E. U. Ekong Library, University of Port Harcourt, \\ Port Harcourt, Rivers State, Nigeria
}

\author{
helenemasealu@yahoo.co.uk; susan.umeozor@uniport.edu.ng
}

\begin{abstract}
The paper reviewed the emerging roles of the $21^{\text {st }}$ century librarians who are managers of repository services across libraries in present day information technology environments. Librarians need to be trained in requisite skills and be empowered for successful management of the ICT driven repository initiatives of the $21^{\text {st }}$ century. Literature was reviewed on the roles and responsibilities of librarians, training needs and opportunities, career path of librarians, and community support necessary for effective and efficient implementation and management of repository initiatives. This entails the ability to comprehend trends and change patterns which are essential for providing research focused and user friendly models in open repository services, based on thorough analytical understanding of the challenges of emerging trends. Librarians need training and retraining in order to reposition themselves in their career path. The library is an integral part of its social environment, that is to educate the community about the existence of an open repository; building partnership with community-oriented research centres through seminars, workshops, symposium, training, and awareness programmes. The paper recommends that librarians should strategize and collaborate with researchers to make open repository an essential research tool.
\end{abstract}

Keywords: Repository services, Academic libraries, Emerging trends, Role of librarians, Developing countries.

\section{Introduction}

Training and re-training of personnel are essential part of every organization and have become paramount in all aspect of operations in the modern world. The emergence of technologies has made the concept of training and re-training a necessity for all concerned. Hence, to be operationally effective, every organization has to embrace this concept. The library is becoming inundated with information and communication technologies. According to Ajidahun (2007), the wonders and innovations of technologies are being propagated in educational, social, political and eco-

Material published as part of this publication, either on-line or in print, is copyrighted by the Informing Science Institute. Permission to make digital or paper copy of part or all of these works for personal or classroom use is granted without fee provided that the copies are not made or distributed for profit or commercial advantage AND that copies 1) bear this notice in full and 2) give the full citation on the first page. It is permissible to abstract these works so long as credit is given. To copy in all other cases or to republish or to post on a server or to redistribute to lists requires specific permission and payment of a fee. Contact Publisher@,InformingScience.org to request redistribution permission. nomic circles. Suffice it to say that managing this system of information and communication in the library necessitates the acquisition of new skills to accommodate latest developments in librarianship. Thus, training and retraining are very crucial in librarianship especially in this era of open repository system. 
Open Repository system is an electronic service designed to preserve and provide access to journal articles, audio, video and other data (Santa Barbara University Library, 2012). Repositories may be maintained by an institution for the benefit of its own authors and researchers or be open to deposits from any researcher in a given subject area. In effect, it can be likened to an online archive with the primary function of collecting, preserving, and disseminating journal articles, thesis and dissertations, among others. It provides global visibility for an institution's scholarly research works.

Transiting from an institutional repository to a broader array of academic and research services, which is a fundamentally online research tool, has necessitated change in the role librarians. According to Basefsky (2009), the library in today's world must transform itself into an agent of change if it is to remain useful and for the institutions they serve to prosper. Change in this sense becomes a necessity for survival in the information business. Librarians who are skilled, innovative, and adaptable need to re-strategize their knowledge in the direction of dispensing repository services as a valuable research tool.

Repositories in Nigerian Academic libraries are in their various stages of transforming into an online academic research service. Several efforts have been made to drive the issue of digitization in Nigeria needed to enhance access and utilization. It is a means of creating a database of materials such as theses and dissertations and other resources that are worthy of preservation. The Association of African Universities (AAU) championed the development of Database of African Theses and Dissertation (DATAD) in 2003 with the goal of improving the visibility of African scholarly work. The aim of this project, set up by the Association of African Universities (AAU), was to digitize thesis and dissertations. This led to the organization of the National Interactive Seminar on Digitization of Library Materials, Processes and Tools which was organized by the National Library of Nigeria (Okiy, 2008). Efforts are continuing in the development of open repository systems in the Nigerian libraries. This paper reviews and considers the new roles and responsibilities of librarians, the training needs and opportunities, career path of librarians, and community support needed in effective and efficient management of repository initiatives.

The challenges of integrating electronic resources and technologies are many, and many-faceted, these challenges have been categorized into three, which are the following.

\section{a. Resource Development}

Beyond task-oriented considerations, such as the selection process itself, there are largescale management issues to consider such as budget, policy, personnel, and technology. Demas (1994) in Schamber (1996) explains that electronic publishing has profound implications for resource development, which is defined as the intentional and systematic building of the set of information resources to which the library provides access. This is a problem because of the shift in library philosophy from ownership of locally stored resources to provision of access to electronically stored resources and the need for rethinking collection development policy, both to support the new philosophy and to better deal with new types of resources on a day-to-day basis. The principles of collection development, which were developed in the world of print publications, do not change radically with new publishing technologies, however, methods of decision making and specific selection guidelines must be adjusted significantly to incorporate new publishing formats. Librarians need to engage in aggressive resource collections, especially electronic technologies (for easy access of other resources in non-print format) that would shift the library services from face-face based services to online, digital (machine-readable intellectual texts) and use of social network in interaction with patrons. 


\section{b. Acquisition}

Smith and Johnson (1993) suggest that libraries should reverse the approach that they have followed throughout the print era: rather than buying as much as they possibly can to respond to any present or potential need, they should acquire only the most heavily and regularly used material for processing and retention. The availability of many information resources, such as electronic search engines, electronic resources and databases, brings information at a click of the button to information users. Therefore, to keep in line with this change, the librarians need repositioning of the information business from materialoriented services to client-oriented services. As resource person, the librarian is tasked with maintaining subscription to various databases in order to have in its digital holding current resources and be able to provide access to patrons.

\section{c. Inter-librarianship}

This is concerned with the sharing of information resources and knowledge creation through networking. It is suggested that information technologies and inter-librarianship be incorporated in the library services to better the information business. Olorunfemi and Mostert (2013) recommended that libraries should improve their ICT facilities and provision of e-resources. In addition to this, university managers should actively search for ways to minimize disruptions such as erratic power supplies, low bandwidth, lack of computers, and payment of fees for Internet access, which are often big impediments to successful inter-librarianship.

\section{Training Needs and Opportunity}

Library repositories are experiencing transition and information explosion and librarians need training to be able to manage the situation effectively. Evidently, the rate of declining services in most libraries today trickles down to limited investment in the training and developing of library personnel. Repositories are rapidly becoming ubiquitous in research institutions and libraries need to play an active role in service development, even when libraries are reassessing their service portfolios in response to budget reductions, each needs to be developing expertise in this arena to participate in shaping these essential services (Association of Research Libraries, 2009). Foresighted librarians will understand that this would serve as a perfect time to invest even more in the training and development of the library staff to become competent enough to take on the new challenges.

Staff training and development are activities that can make a very significant contribution to the overall effectiveness and efficiency of any organization or institution. As the repository systems undergo transition and restructure, the library is better poised to function effectively as a digital academic research tool thorough understanding of the current demand and challenges. Re-training also provides staff with the basic knowledge of new concepts when the previous training received has become outdated due to constant changes in trends. Thus, the library management should encourage training and re-training of their staff by facilitating access to technical skills and entrepreneurial training certification and the pursuit of associate, graduate and post-graduate degrees as well as access to funds, grants, and loans. Through training and development of staff, individuals are afforded the opportunity to develop themselves and critically evaluate their effectiveness and reposition their professional roles.

\section{Librarians Role and Trends in Repository Services}

The role of the librarian should emphasize the online accessibility aspect of institutional repositories. Initially, the institutional repository, even though digitally managed, was not widely shared 
by researchers. This may be accounted for by lack of awareness. Very few researchers are actually aware of the existence or usage of information therein. The repository system is meant to serve several purposes, such as research aid, information bank, and social academic data, but in most cases, repositories are not fully utilized. The new roles and responsibilities of library staff with regards to repository system are categorized into six segments including the following.

\section{Management Role and Copyright Issue}

Management role in any institution is dependent on the human resources of such organization. The focal point here entails creating an advanced user friendly model which would be relatively easy to manipulate. The functions include gathering all available research data, selecting, appraising and clarifying them, and publishing and sharing them digitally for library subscribers to access. Walters (2007) stated that digital repositories would transform librarianship in such a way that they would no longer be passive receivers of information but active disseminators of intellectual output for entire universities. Data in the repository system must be inter-shared with other repositories so as to avoid information underuse.

Copyright Issue refers to the right of an individual to intellectual property. This role poses a great challenge in digitizing the intellectual resources of the repository, because librarians may not be able to provide effective access to the digital information due to copyright law. Therefore, the management role does not end at systematic collection, analysis, and digitization of information but also managing the copyright situation. This can be equated to negotiation between information producers and information users. Eke (2011) noted that Intellectual property is the fifth challenge stated by Library of Congress as one of the challenges in building an effective digital library. Eke stated that a key element for digital libraries is appropriate recognition and protection of legal rights such as copyright, publicity, privacy, matter of obscenity, and defamation of intellectual property as well as less legalistic but serious concerns associated with the ethics of sharing or providing access to fold or ethnographic materials. In a situation in which the owners of information feel reluctant in granting access to their work due to fear of loss of money attached to such research work, the librarian should manage this situation by initiating the fair usage policy a situation whereby the information customers have to subscribe in order to gain access to such work.

\section{Awareness Creation and Interconnectivity Role}

The librarian, as agent of change, needs to team up with other librarians to ensure that information is shared and accessible to researchers and information users. The role of awareness creation becomes paramount in this aspect. This process ameliorates the inaccessibility of information in the repository database. In order to create a social academic research tool, the librarians need to work hand in hand to share their institutional repository content. This would ensure effective dissemination of repository information.

\section{Academic Digital Publisher}

Walters (2007) opined that the rise of digital repositories is helping libraries reinvent themselves. The era of strict institutional repository is fading away with the current modification in repositories across libraries as information banks. The benefits to libraries and universities creating digital repositories are great as libraries restructure, pursue collaborations, and re-position themselves to become major digital publishers and broadcasters in the scholarly world (Walters, 2007). This affords librarians the opportunity to publish information and details of research works online to subscribers. 


\section{Solicitor (Change Agent)}

Appraising the library as an institution of change cannot be farfetched from the role of the librarian in adequately making sure that every bit of information the librarian gets is readily accessible to the targeted audience. Change in this regard cannot take effect if people are not informed. In effect, when information is readily available to users as is required through the services of digital repository systems, the supposed intention of researchers gets to the people and makes them informed and knowledgeable citizens.

\section{Digital Resource Person}

Research has proved that the use of mobile phones and computer gadgets with internet facility is rapidly eroding the conventional practice of visiting the library. Through repositories, the librarian is better positioned to still perform the purpose they are professionally known for. Basefsky (2009) proposed that information gathering, dissemination, and discussion in the form of library service must become a crucial part of researchers' networks. The librarian must incorporate these roles to serve better as a digital resource person as the current trend demands.

\section{Information Literacy}

Information needs vary among information users. Conventionally, the role of librarians is deeply rooted in the provision of timely information services and resources to patrons. However, the emergence of Information Communication Technology (ICT) in the information industry calls for re-strategization, as the ICT era created information overload. This adversely affects the role of information professionals in the new order. Lancaster (1997) stated that in order to justify its existence in the electronic world, the library must continue to perform one of the most important functions in the traditional mode of print-on-paper world as well as organizing the universe of resources in a way that the most relevant information resources are made most accessible to the user community. Nevertheless, behind every danger lurk some arrays of opportunities - opportunities for the information professionals to rebrand and reposition their professional roles. Many information resources abound outside the library holdings and are found at the finger tip of interested users. However, the information therein is unrefined as against the information needs of users. Hashim and Mokhtar (2012) stated that we live in an information society where developments of information technology and telecommunication networks are accompanied by a corresponding increase in knowledge, with a rapidly growing flow of information. This new information environment requires new skills in seeking, processing, and using information. The base for individual ability to understand and use information is a qualitative, ongoing learning process. Learning and education are important topics in the information society and the educational situation is changing for several reasons, which develop from the social, cultural, political, and economic changes in the society. The role of librarians and information professionals in this new environment has been strongly influenced by these changes.

This requires 'Participatory Librarianship' to get in touch with users and assist them become information managers. This should equip them with the ability to manipulate the numerous information resources leading to accurate and appropriate information based on their individual information needs. This it is believed would help in promoting information literacy and importantly the role and responsibility of librarians in the new era.

\section{Trends in Training}

The innovation of information and communication technology (ICT) has created along with it a lot of gap not only in library and information services but also in the roles and expectations of the information professionals, particularly from the perspectives of the client. Hashim and Mokhtar 
(2012) asserted that librarians are expected to do more and more with fewer and fewer people. There is a danger that librarians and information professionals will be left behind if they insist on the old role of the traditional librarians. To keep abreast, library professionals should at all times pursue skill enhancement through training to meet up with the nature of the new era in library services. Training is an organized process primarily aimed at impacting the receivers to improve performance or output. According to H. Singh (2012), training is a learning process that involves the acquisition of knowledge, sharpening of skills, concepts, rules, or changing of attitudes and behaviours to enhance the performance of employees. In addition to the basic training required for a trade, occupation, or profession, observers in the labor-market have recognized since 2008 the need to continue training beyond initial qualifications to maintain, upgrade and update skills throughout working life (G. Singh, 2014).

The intricacies brought about by the information and communication technology of the $21^{\text {st }}$ century have repositioned the traditional roles and responsibility of librarians in that it becomes a 'change or perish' situation for informational professionals. Toffler (2011) opined that the illiterate of the 21 st century will not be those who cannot read and write, but those who cannot learn, unlearn, and relearn. The trends where librarians are expected to develop or include in the library and information services to inculcate the intricacies of the new era information business are summarized in Table 1.

Table 1: Trends in 21st librarianship training.

\begin{tabular}{|l|}
\hline Enhanced collection development in all format (print and digital) \\
\hline Participatory librarianship and library educators (information literacy) \\
\hline ICT compliancy library \\
\hline Enhanced information management skill \\
\hline Client-oriented services \\
\hline $\begin{array}{l}\text { Technical and human relation skills - this involves hard Skills Training (such as computer skills, } \\
\text { anguage skills, statistics, and others) and soft skills training, dealing with more intangible skills }\end{array}$ \\
\hline Digital librarianship (media resources manager) \\
\hline Custodians of refined information (appropriate, authentic and accurate) \\
\hline Entrepreneurs of Information \\
\hline Partnership with community (town and gown relationship) \\
\hline Liaison officers - leveraging between patrons and information \\
\hline Information marketers. \\
\hline
\end{tabular}

\section{Career Path}

A career path is a line of specialization that provides direction towards professional development in a chosen career. It motivates and enhances workers' imagination and commitment. Transition of an institutional repository to a digital academic research tool presents challenges and opportunities. Digital sharing of academic research data through the system of open repositories could be said to have its root in the traditional role of librarians managing books and making them accessible to readers and researchers as well. The world is currently dominated by digital communication and information technology, and, as such, people flow with this trend of digitalized services. 
In the business of information sharing, the traditional setting of visiting the library for information is dwindling at a rapid rate. Consequently, many librarians are redefining their roles on to how to effectively manage digital information. In effect, librarians, as information officers, should keep in touch with the demands of their roles and should be on track in order to improve on the new opportunities. In summary, open repository provides an avenue which librarians could use to chart a new course within the profession, their career path and development.

\section{Community Support}

Building partnerships with community-oriented research centres and departments is one of the best ways to develop an institutional repository into a valued community resource. The repository plays a central role in a project that includes student internships, physical exhibits, and even an original theatrical production. Engaging new and strategic stakeholders from the community bridges the gap between library staff and the community. This could bring about great ally and helping hands in the repository initiative and it can also help to spread the word to community members about the repository and its services. This can be achieved through seminars, workshops, symposia, training, and awareness programmes and this can help to identify people whose needs may be served by the repository.

\section{Conclusion and Recommendation}

Repository systems could be likened to mobile information banks, because they can be accessed anytime and anywhere. The institutional repository presents new roles and responsibilities for the librarians who need to be able to handle the new challenges and demands to make the institutional repository an essential research tool. The paper has reviewed current trends and the emerging roles and responsibilities of librarians highlighting the task of library management in the training of their staff towards making institutional repository an effective information resource tool for researchers. Therefore, the study recommends that the community has a role to play in supporting the initiation of repository as social academic research information tool. Also, librarians need to strategize and collaborate with researchers to make open repository an essential research tool.

\section{References}

Association of Research Libraries, (2009). The research library's role in digital repository services. Final report of the ARL Digital Repository Issues Task Force. January 2009.

Ajidahun C.O. (2007). The development and education of library manpower in information technology in university libraries in Nigeria. World libraries, 17(1), $44-66$. Available at http://ojsserv.dom.edu/ojs/index.php/worldlib/article/view/44/66.

Basefsky, S. (2009). The end of institutional repositories and the beginning of social academic research service: An enhanced role for libraries. Paper presented and published in conference proceedings at IRL conference, Cornell University USA. June 2009: 7 - 14. Available at http://digitalcommons.irl.cornell.edu/conference/7

Eke, H. N. (2011) Digitizing resources for University of Nigeria Repository: Process and Challenges. Webology Article, 8(1). Available at http://www.webology.org/2011/v8n1/a85.html

Hashim, L.B., \& Mokhtar, W. (2012). Preparing new era librarians and information professionals: Trends and issues. International Journal of Humanities and Social Science, 2(7), 151-156.

Lancaster, F.W. (1997). Artificial intelligence and expert system technologies prospects. Libraries for the new millennium: Implication for managers. London: Library Association Pub. 19 - 37.

Okiy, R. B. (2008). Digitizing and archiving information resources in libraries: Reactions to global initiatives from Nigeria. IFLA ITS Newsletter, December 2008, 5-6. 
Olorunfemi, D. Y., \& Mostert, J. (2013). Information seeking behavior of law students at Adekunle Ajasin University, Nigeria (AAUA). Models in information seeking behaviour. A paper presented at European Conference on Information Literacy. Retrieved from http://ecil2013.ilconf.org/wpcontent/uploads/2013/11/olorunfemi_Yemisi_Janneke_InformationSeekingBehaviour.pdf

Santa Barbara Library University of California. (2012). Article on open access repositories scholarly communication. Available at www.library.ucsb.edu/scholarly-communication/open-access-repositories

Schamber, L. (1996). Library collection development in an electronic age. ERIC Digest (ED392467). Available at www.ericdigests.org/1996-4/library.htm

Singh, G. (2014). Impact of training on job performance at diesel locomotive work. Journal of Management Research and Analysis, 1(1), 27-41.

Singh H. (2012) Training and development: A prominent determinant for improving human resource productivity. International Conference on Management and Education Innovation, Vol. 37. Retrieved on 7 March, 2016 from http://www.ipedr.com/vol37/053-ICMEI2012-E10061.pdf

Smith, E., \& Johnson, P. (1993) How to survive the present while preparing for the future: A research library strategy. College and Research Libraries, September, 389-396.

Toffler, A. (2011). Quotes. Available at www.goodreads.com/quotes/8800

Walters, T. O. (2007). Reinventing the library: How repositories are causing librarians to rethink their professional roles. Libraries and the Academy, 7(2), 213-225.

\section{Biographies}

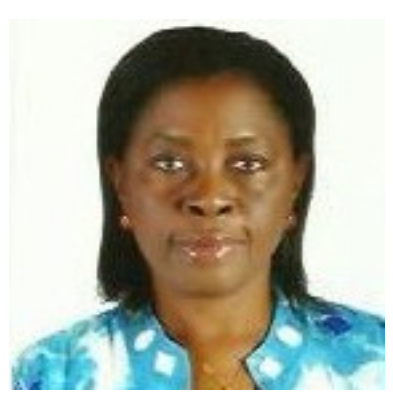

Dr. Helen Uzoezi Emasealu graduated with a B.A. in Russian Language 1991, Masters in Library Science, (MLS) 1998, and a Doctorate Degree (Ph.D), 2014, in Library and information Science from the University of Ibadan, Nigeria. She was appointed Subject Librarian in 2006 at the University of Port Harcourt. She has worked as subject librarian in the Faculties of Social Sciences and Humanities; Reference Librarian, Reader Services; Research Librarian on secondment to the Institute of Petroleum Studies (IPS). She pioneered the building and development of the IPS Library Collection, and the management of its electronic resources. She was Editor of IPS Newsletter, Egbogah Lecture Series and Coordinator, IPS Publications; and Medical librarian, College of Health Sciences, University of Port Harcourt. Dr. Helen is currently the Head Readers' Services at Donald E.U. Ekong Library, University of Port Harcourt, Nigeria. Among other publications, she coauthored, "The Changing Role of Academic Libraries: A Focus of Five Higher Institutions in Nigeria" in the International Journal of Educational Organization and Leadership. Her hobbies include travelling, watching documentaries, listening to music and meeting people.

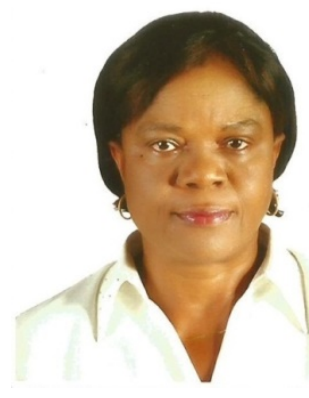

Dr. Susan N. Umeozor obtained a B.A. in Psychology 1985 from North Carolina State University, Raleigh and a Masters in Library Science (MLS) 1987, from North Carolina Central University, Durham, USA. Among other publications, she is the author of "Human Resources, User Education Marketing Strategy, and Students' Use of Library Services in Some Nigerian Federal Universities" published in Library Philosophy and Practice (University of Nebraska-Lincoln, 2013). This article has garnered over 290 downloads. She is currently the University Librarian at Donald E.U. Ekong Library, University of Port Harcourt, Nigeria. She enjoys travelling, music and listening to the news. 